\title{
Influence of Growth Regulators on Callogenesis and Somatic Embryo Development in Date Palm (Phoenix dactylifera L.) Sahelian Cultivars
}

\author{
Djibril Sané, ${ }^{1}$ Frédérique Aberlenc-Bertossi, ${ }^{2}$ Léopold Ibrahima Djitiningo Diatta, ${ }^{1}$ \\ Badara Guèye, ${ }^{1}$ Abdourahman Daher, ${ }^{3}$ Maurice Sagna, ${ }^{1}$ Yves Duval, ${ }^{2}$ and Alain Borgel ${ }^{2}$ \\ ${ }^{1}$ Département de Biologie Végétale, Université Cheikh Anta Diop, BP 5005, Dakar-Fann, Senegal \\ ${ }^{2}$ Institut de Recherche pour le Développement, IRD, BP 64501, 34394 Montpellier Cedex 5, France \\ ${ }^{3}$ Institut des sciences de la vie, Centre d'Etudes et de Recherche de Djibouti (BP 486), BP 5005, Dakar-Fann, Djibouti
}

Correspondence should be addressed to Djibril Sané, djisane@refer.sn

Received 21 October 2011; Accepted 8 December 2011

Academic Editor: Hilbert Jean Louis

Copyright (C) 2012 Djibril Sané et al. This is an open access article distributed under the Creative Commons Attribution License, which permits unrestricted use, distribution, and reproduction in any medium, provided the original work is properly cited.

\begin{abstract}
This study provides a physiological analysis of somatic embryogenesis in four elite cultivars of date palms: Ahmar, Amsekhsi, Tijib, and Amaside, from the initial callogenesis to establishment and proliferation of embryogenic suspension cultures. Somatic embryos development and in vitro plants rooting were also studied. For each step, auxins and cytokinins concentrations were optimised. The primary callogenesis from leaf explants of seedlings appeared highly dependent on genotype. Ahmar (80\%) and Amsekhsi (76\%) appeared highly callogenic, whereas Tijib (10\%) and Amaside (2\%) produced low amounts of calluses. 2,4Dichlorophenoxyacetic acid appeared favorable to the induction of primary callogenesis and its effect was enhanced by the addition of benzyl adenine or adenine sulfate. Secondary friable calli obtained from chopped granular calli were used to initiate embryogenic cell suspensions in media supplied with 2,4-dichlorophenoxyacetic acid. Suspension cultures showed a growth rate of fourfold after four subcultures in presence of 2,4-dichlorophenoxyacetic acid $2 \mathrm{mg} / \mathrm{L}$. Our results showed that a seven-day transitory treatment with benzyl adenine $0,5 \mathrm{mg} / \mathrm{L}$ was necessary to optimize embryos development. Naphthalene acetic acid induced the development of primary orthogravitropic roots during embryos germination. The comparison with cytofluorometry of nuclear DNA amounts showed no significant difference in ploidy level between regenerated plants and seedlings.
\end{abstract}

\section{Introduction}

The date palm (Phonix dactylifera L.) is a dioecious perennial species of the Arecaceae family, adapted to arid zones where it plays an economic role thanks to the production of dates. Date palm plantations which often constitute the framework of oases mainly encountered in North Africa, Middle East, and Sahel are traditionally propagated by seeds or offshoots. To ensure the renewal and extension of date palm groves, in vitro micropropagation techniques have been developed from zygotic embryos, axillary buds, and immature leaves [1-4]. Date palm micropropagation through somatic embryogenesis has been previously reported [5, 6]. The use of embryogenic suspension cultures improved the yields of the regeneration processes and allowed largescale propagation of several date palm cultivars $[5,7-9]$.
Recently, regeneration through somatic embryogenesis from embryogenic suspensions culture was obtained for the first time for the Sahelian cultivar Amsekhsi [10].

However, the efficiency of various somatic embryogenesis protocols described for date palm depends on the cultivars, some of them being recalcitrant to in vitro culture $[9,11]$. One of the major bottlenecks in regeneration procedures is the production of primary calli. Exogenous auxins and cytokinins are the main plant growth regulators (PGRs) involved in the control of cell division and differentiation [12]. The role of these PGRs in the regeneration performance of date palm has been previously described [8-10].

It is therefore of importance to optimise the somatic embryogenesis conditions in order to extend the regeneration protocols to genotypes which are specifically adapted to the sahelian edaphoclimatic conditions. In the present study, 
the effect of various PGRs, particularly of the auxins, 2,4dichlorophenoxyacetic acid (2,4-D) and naphthalene acetic acid (NAA), and of the cytokines, benzyl adenine (BA) and adenine sulfate on the callogenesis of four sahelian cultivars was explored. The hormonal conditions for the proliferation of embryogenic cell suspensions, the development of somatic embryos, and the rooting of vitroplants were also investigated. The nuclear DNA content of regenerated plantlets was controlled by flow cytometry.

\section{Material and Methods}

2.1. Plant Material and Preparation of Explants. Our study was implemented from seeds obtained from four cultivars, namely: Ahmar, Amsekhsi, Tijib, and Amaside harvested in plantations in the Atar region (Mauritania).

The seeds were sterilised with $96 \% \mathrm{H}_{2} \mathrm{SO}_{4}$ for $10 \mathrm{~min}$ then rinsed with sterile distilled water. They were then soaked in sterile water for $24 \mathrm{~h}$ before being transferred onto glass tubes $(25 \times 150 \mathrm{~mm})$ containing $20 \mathrm{~mL}$ of agar (Difco Agar) $(8 \mathrm{~g} / \mathrm{L})$. After one month of culture in a controlled culture room with a $12 \mathrm{~h} / 12 \mathrm{~h}$ photoperiod and a light flow of $80 \mu \mathrm{E} \cdot \mathrm{s}^{-1} \cdot \mathrm{m}^{-2}$, at $27^{\circ} \pm 0.2^{\circ} \mathrm{C}$, the seedlings where dissected. Young leaves were cut into segments of $1 \mathrm{~cm}$ in length. All the explants were transferred for callus induction on various growth regulators concentrations.

2.2. Primary and Secondary Callogenesis. For each of the 4 studied cultivars, 48 segments were used by type of explant (shoots or roots) and by medium condition. The explants were placed on a basic medium composed of Murashige and Skoog solution [13], FeEDTA, Morel and Wetmore vitamins [14], biotin $(0.01 \mathrm{mg} / \mathrm{L})$, sodium ascorbate $(100 \mathrm{mg} / \mathrm{L})$, and myoinositol $(100 \mathrm{mg} / \mathrm{L})$ [10]. This medium was supplied with sucrose $(30 \mathrm{~g} / \mathrm{L})$, agar (Difco Agar) $(8 \mathrm{~g} / \mathrm{L})$, and increasing concentrations of $2,4-\mathrm{D}(1,2,4,8$, or $16 \mathrm{mg} / \mathrm{L})$ or NAA $(2$ or $4 \mathrm{mg} / \mathrm{L})$ combined or not with BA $(1 \mathrm{mg} / \mathrm{L})$ or adenine sulfate $(40 \mathrm{mg} / \mathrm{L})$. The $\mathrm{pH}$ was adjusted to 5.5 . The effect of the hormonal composition was evaluated by counting of the calluses obtained after 2 months of culture in the dark at 27 $\pm 0.2^{\circ} \mathrm{C}$.

The primary calluses were chopped with a scalpel according to Teixeira et al. [15] and transferred on the basic medium supplied with 2,4-D (2 mg/L). After one month, secondary calluses were used for the installation of embryogenic suspension cultures. They were placed in Erlenmeyers flasks containing $50 \mathrm{~mL}$ liquid medium of the same composition without agar and cultivated on an orbital shaker at $90 \mathrm{rpm}$ in light $\left(80 \mu \mathrm{E} \cdot \mathrm{s}^{-1} \cdot \mathrm{m}^{-2}\right)$ with a photoperiod of $12 \mathrm{~h} / 12 \mathrm{~h}$ at $27 \pm 0.2^{\circ} \mathrm{C}$.

2.3. Establishment of Embryogenic Suspension Cultures. The protocol used is adapted from that described in the oil palm [16]. Each month, $300 \mathrm{mg}$ fresh weight (FW) of cell suspensions was transferred onto a liquid medium containing the basic medium supplemented with $20 \mathrm{~g} / \mathrm{L}$ of glucose. The effect of 2,4-D, used at $2 \mathrm{mg} \mathrm{L}^{-1}$ without activated charcoal or at 50,75 and $100 \mathrm{mg} \cdot \mathrm{L}^{-1}$ with activated charcoal $(1 \mathrm{~g} / \mathrm{L})$ was evaluated by monitoring growth rates of the suspension cultures. For each condition, FW of proembryogenic masses (PEMs) was measured monthly during four subcultures (five repetitions).

2.4. Development of Somatic Embryos. In order to produce somatic embryos, the suspensions were cultivated for one month in a liquid medium containing the basic medium without hormone. Suspensions were then filtered through a double nylon mesh ( 1 and $2 \mathrm{~mm}$ ). PEMs (50 mg FW) were transferred for one week onto a filter paper in a $9 \mathrm{~cm}$ diameter Petri dish containing $20 \mathrm{~mL}$ of basic medium enriched with sucrose $60 \mathrm{~g} \mathrm{~L}^{-1}$ and containing $0,0,5 ; 1$; 1,5 , or $2 \mathrm{mg} / \mathrm{L}$ of $\mathrm{BA}$ and gelified with agar at $8 \mathrm{~g} / \mathrm{L}$. For each culture condition, 5 Petri dishes were used. The filter papers and the cultures were then transferred on the same medium deprived of hormone and subcultured weekly during five weeks. The effect of the application of various BA concentrations on the evolution of PEMs biomass and the growth (number and size) of somatic embryos was then evaluated.

2.5. Germination of Somatic Embryos and Rooting. Developed somatic embryos (length 10 to $11 \mathrm{~mm}$ ) were transferred for germination in individual glass tubes $(25 \times 150 \mathrm{~mm})$ on Murashige and Skoog medium [13], with or without NAA $(1 \mathrm{mg} / \mathrm{L})$. For each conditions, 48 embryos were used. The effect of NAA on the morphology of the root system was evaluated by the number and the length of roots produced after 4 weeks of culture. The rooted plantlets were then transferred in the greenhouse.

2.6. Cytofluorimetric Analysis of Ploïdy Level. The genetic stability of the clones was estimated by measuring the nuclear DNA content in in vitro plantlets and seedlings. The method developed by flow cytometry was performed using an argon laser cytometer $(15 \mathrm{~mW})$ (FAC-Scan, Becton Dickinson) with emission at $488 \mathrm{~nm}$ [17]. The extraction of interphasic nuclei was carried out by manual chopping of $30 \mathrm{mg}$ of the sample in $1.5 \mathrm{~mL}$ of lysing buffer $[18,19]$. Nuclei were stained with $330 \mu \mathrm{g} \cdot \mathrm{mL}^{-1}$ propidium iodide during $5 \mathrm{~min}$ on ice. Each sample was analyzed on the basis of 5 independent repetitions. For each analysis, 3,000 nuclei were measured. Fluorescent latex beads ( $2 \mu \mathrm{m}$ diameter) were used as internal standard. The estimation of the nuclear DNA content was carried out from foliar segments of same developmental stages harvested on in vitro plantlets from three clones from the cultivar Ahmar (Ahm A1, Ahm A8, and Ahm A14-F) and three clones of Amsekhsi (Amse A56, Amse A57, and Amse A72). Foliar segments were obtained from the germination of seeds of the same cultivars. The size of the date palm genome was compared to that of the reference rice variety Nippon Bar $(2 \mathrm{C}=1.00 \mathrm{pg})[17]$.

2.7. Statistical Analysis. For each stage of somatic embryogenesis, the experimental design was randomized. Statistical analyses were carried out by using the Linear Model ANOVA/MANOVA of STATISTICA (analysis software system dated), version 6. StatSoft, Inc. (2001). The treatments 


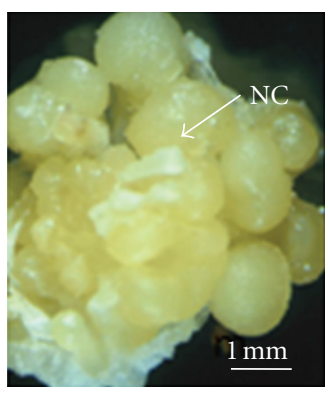

(a)

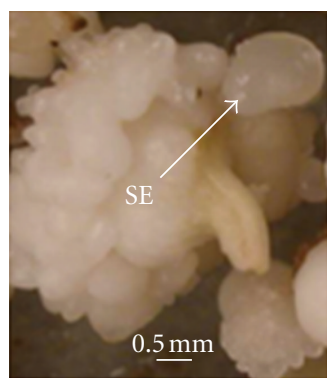

(d)

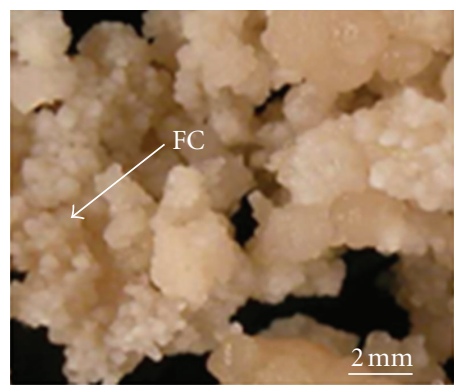

(b)

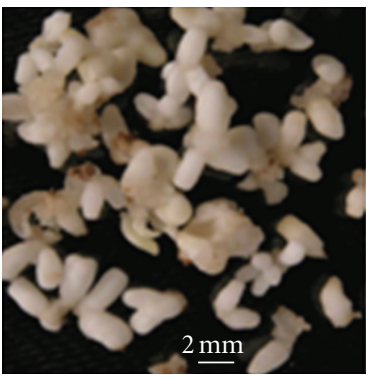

(e)

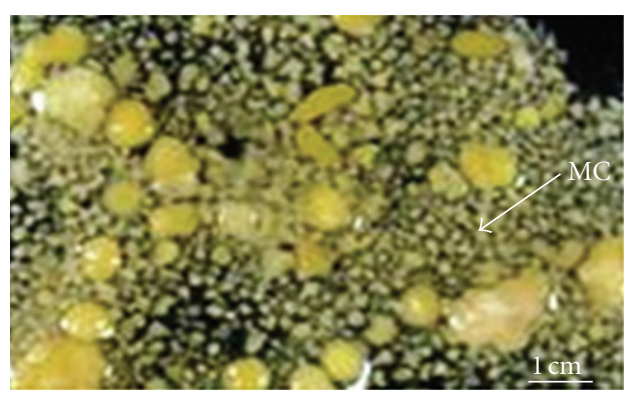

(c)

FIGURE 1: Callogenesis and development of date palm somatic embryos. (a) compact nodular primary callus obtained from foliar explants after 2 months on 2,4-D ( $\left.2 \mathrm{mg} \mathrm{l}^{-1}\right)$ containing medium; (b) friable secondary callus obtained 1 month after chopping of the primary callus; (c) suspension culture; (d) somatic embryos of stage I, (e) stage, II and III (f), respectively, after 2, 4, and 6 weeks of culture on PGR-free medium; (g) germinated somatic embryo. NC: Nodular callus, FC: Friable callus, MC: microcallus, SE: somatic embryo.

were discriminated by multiple mean comparison of aftervariance analysis followed by Newman and Keuls test (threshold 5\%) or by Pearson's Chi-squared test.

\section{Results}

3.1. Callogenic Capacity Depends on the Cultivars and the PGR Composition of the Medium. The effect of PGRs (auxins and cytokines) on the callogenesis capacity of foliar and root explants was evaluated for the four date palm cultivars studied. The observations carried out after 8 weeks of culture revealed the elongation of all the roots segments placed in culture. However, no callus formation was observed on root explants, whatever the hormonal combination tested. On the other hand, a morphogenetic activity characterized by the proliferation of compact granular callus was observed on foliar explants after 4 weeks of culture in 2,4-Dcontaining mediums. From 2 to $3 \mathrm{~mm}$ in diameter, these callus developed and reached a 6-7 mm size after 8 weeks (Figure 1(a)).

The effect of auxin on callogenesis from foliar explants was studied for the four sahelian cultivars (Figure 2). Two of the 4 cultivars (Ahmar and Amsekhsi) were found to be very callogenic (resp. $80 \%$ and $76 \%$ ), whereas Tijib and Amaside exhibited very low callusing rates (resp. 10\% and $2 \%)$. For the two most callogenic cultivars, almost no callus formation was observed in the presence of NAA only or combined with BA or adenine sulfate (Figures 2(a) and 2(b)). Callogenesis was mostly observed on 2,4-D-enriched medium. The induction of primary callogenesis required 2,4D concentrations ranging from 2 to $4 \mathrm{mg} / \mathrm{L}$. The addition of BA or adenine induced higher callus frequencies (Figures 2(a) and 2(b)).

When globular and compact primary callus were chopped, they gave rise after between 6 to 8 weeks of culture, to friable granular secondary callus which will be used for the initiation and the installation of embryogenic suspension cultures (Figure 1(b)).

\subsection{Proliferation of the Embryogenic Suspension Cultures.} The cultures (consisting in microcallus suspensions) were established after two subcultures in liquid media enriched with 2,4-D with or without active charcoal (Figure 1(c)). Growth rates were evaluated during 4 successive subcultures for two clones of the Ahmar cultivar, namely, A57 and A72. Figure 3 shows that growth rates were variable depending on both the clone and the 2,4-D level. Variance analysis (95\% threshold) showed very significant differences in growth rates between the 2 clones $(F(3,32)=40.748 ; P=0.000)$. In the presence of activated charcoal, any increase in the amount of 2,4-D beyond $50 \mathrm{mg} / \mathrm{L}$ significantly decreased growth rates. However, whatever the clone considered, the $2 \mathrm{mg} / \mathrm{L}$ concentration of 2,4-D was the most favorable for cellular proliferation, allowing monthly multiplication rates of fourfold.

3.3. Development of Somatic Embryos. The development of somatic embryos was obtained after a one-month cultivation 
TABLE 1: Influence of BAP on the biomass changes in suspension cultures and somatic embryos development after 5 weeks on PGR-free medium.

\begin{tabular}{|c|c|c|c|}
\hline $\mathrm{BA}(\mathrm{mg} / \mathrm{L})$ & $\begin{array}{l}\text { Suspension culture } \\
\text { Fresh weight (g) }\end{array}$ & Embryo number per Petri dish & $\begin{array}{l}\text { Vitreous embryo number per } \\
\text { Petri dish }\end{array}$ \\
\hline 0 & $1.37^{\mathrm{c}}$ & $21^{\mathrm{b}}$ & $1^{\mathrm{e}}$ \\
\hline 0.5 & $1.50^{\mathrm{b}}$ & $29^{\mathrm{a}}$ & $1.5^{\mathrm{d}}$ \\
\hline 1 & $1.63^{\mathrm{ab}}$ & $18^{\mathrm{c}}$ & $3^{c}$ \\
\hline 1.5 & $1.66^{\mathrm{ab}}$ & $14^{\mathrm{d}}$ & $4.7^{\mathrm{b}}$ \\
\hline 2 & $1.77^{\mathrm{ab}}$ & $11^{\mathrm{e}}$ & $5.1^{\mathrm{a}}$ \\
\hline
\end{tabular}

Average values were calculated from 5 repetitions per condition of medium; letters indicate significative differences according to Newman and Keuls test at the level of $5 \%$.

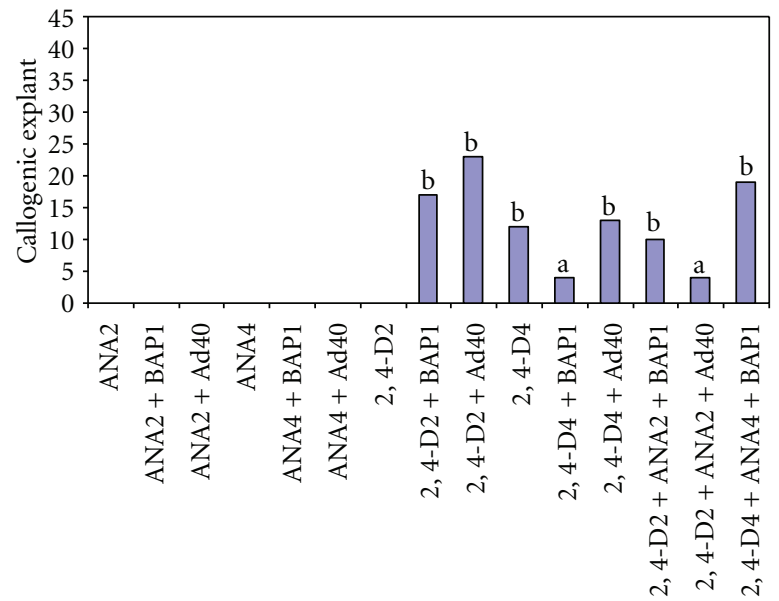

(a)

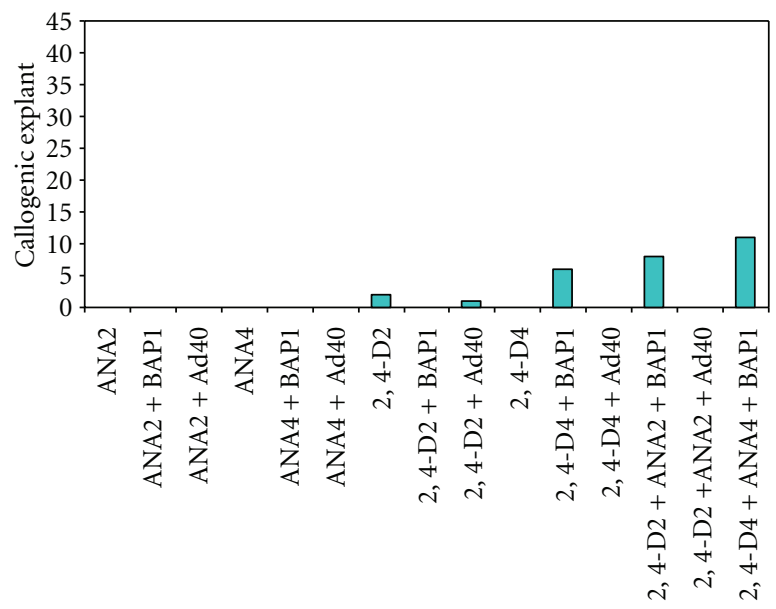

(c)

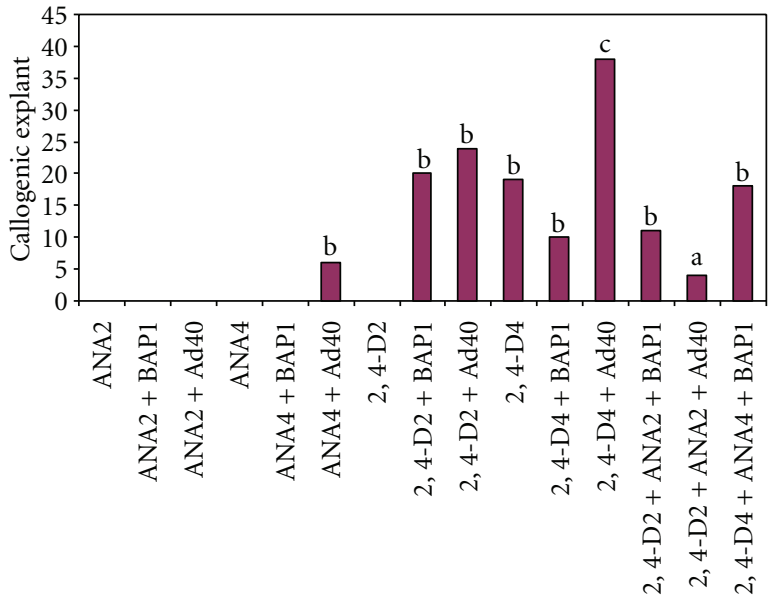

(b)

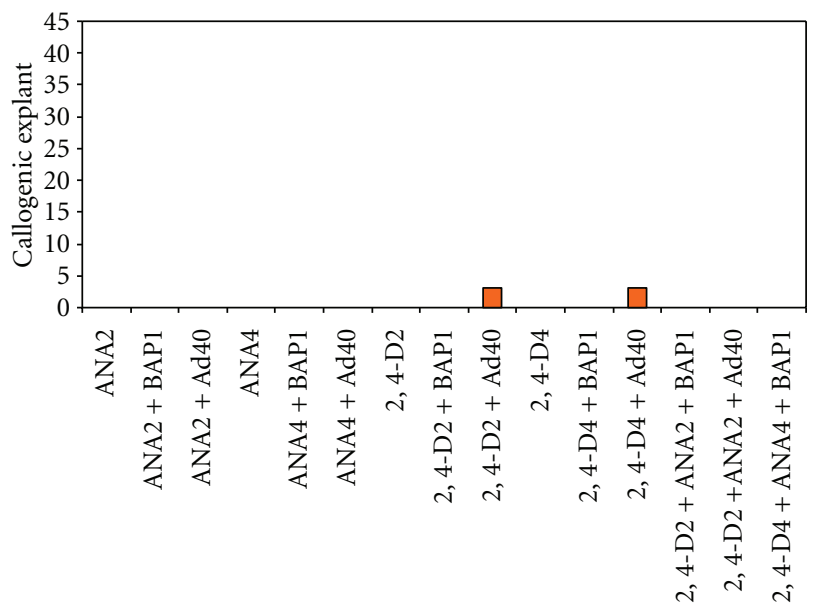

(d)

FIGURE 2: Effect of plant growth regulators (PGRs) in $\mathrm{mg} / \mathrm{L}$ on the induction of callogenesis after 60 days of culture for cultivars Ahmar (a), Amsekshi (b), Tijib (c) and Amaside (d). Means were calculated from 48 explants per condition. Letters indicate significant differences according to Newman and Keuls test at the level of $5 \%$.

period on a PGR-free medium, followed by plating on semisolid medium. The cultures were maintained on BAcontaining medium for 1 week then on PGR-free medium for five weeks. Somatic embryos of stage I (length 1 to $1.5 \mathrm{~mm}, 1 \mathrm{~mm}$ diameter) epidermized and of ovoid shape were observed as of the 2 nd week of culture (Figure $1(\mathrm{~d})$ ). The development of embryos was optimized by a one-week treatment with BA $0.5 \mathrm{mg} / \mathrm{L}$ (on average 29 to 30 embryos from $40 \mathrm{mg}$ of suspension culture) (Table 1). An increase in cytokinin concentration induced a significant decrease of the number of individualized embryos and an increase in the number of vitrified embryos $(F(12,100.83)=6.6151$; $P=0.000)$. The development of somatic embryos of stage II (length 4 to $5 \mathrm{~mm}, 1.5 \mathrm{~mm}$ diameter) was obtained between 


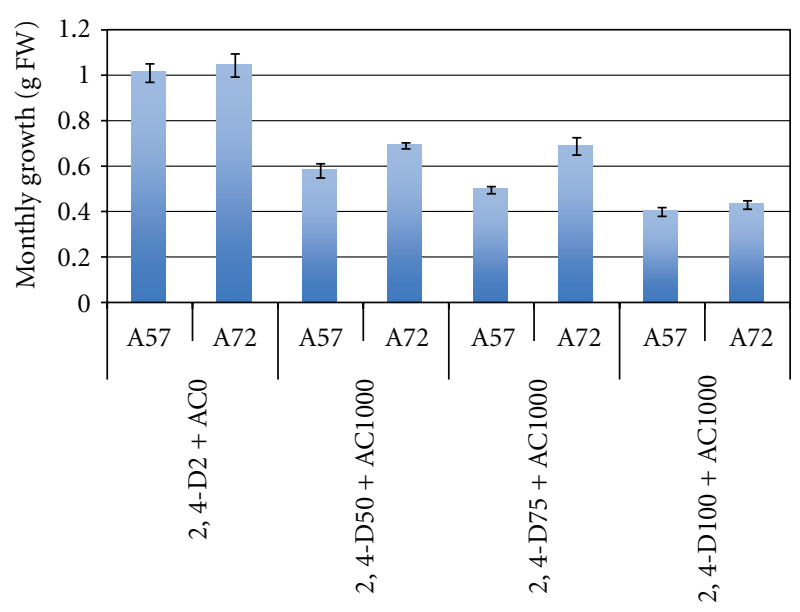

Concentrations $\left(\mathrm{mg} \cdot \mathrm{L}^{-1}\right)$

Figure 3: Effect of 2,4-D (2 mg/L) without activated charcoal (AC) or at 50,75 , and $100 \mathrm{mg} / \mathrm{L}$ with $\mathrm{AC}(1000 \mathrm{mg} / \mathrm{L})$ on growth rates of suspension cultures from two different Ahmar cultivars lines. Averages values were calculated from 5 repetitions per condition of medium; bars indicate confidence interval at 95\% threshold.

the 3rd and the 4th week of culture (Figure 1(e)). After 6 weeks of culture, these embryos developed in chlorophyllous somatic embryos of stage III (length 10 to $11 \mathrm{~mm}, 1.7$ to $2 \mathrm{~mm}$ diameter) (Figure 1(f)).

3.4. Germination of Somatic Embryos and Rooting of Vitroplants. The mature somatic embryos of stage III developed a shoot and a root and germinated with a rate of $82 \%$. The morphology of roots produced after 4 weeks of culture depended on the NAA concentration (Table 2). In a PGR-free medium, plants produced numerous fine and plagiotropic roots, 1.4 to $2.3 \mathrm{~cm}$ long. In contrast, when embryos were cultivated with $1 \mathrm{mg} / \mathrm{L}$ NAA, the plants developed a vigorous and orthotropic root (3.3 to $4.9 \mathrm{~cm}$ long) whose morphology was similar to that obtained during the germination of seedlings (Figure 1(g)).

3.5. Nuclear DNA Content. Measurements of nuclear DNA content were standardized using leaves of Nippon Bar rice variety as an internal standard ( $2 \mathrm{C}=1 \mathrm{pg}$ DNA by nucleus). The size of the genome of Phoenix dactylifera as estimated on seedling leaves from the cultivars Ahmar and Amsekhsi was $2 \mathrm{C}=1.74 \mathrm{pg} /$ nucleus and $2 \mathrm{C}=1.73 \mathrm{pg} /$ nucleus (resp.). No significant difference was found between the values obtained from seedlings and somatic embryo-derived plantlets $(F=$ 0.507; $P=0.82$ ) (Table 3 ). The cytofluorimetric analysis revealed that all the regenerated clonal offsprings were diploïd (Figure 4) as one peak at 2C DNA nuclear content was observed. No $3 \mathrm{C}, 4 \mathrm{C}, 6 \mathrm{C}$, or $8 \mathrm{C}$ peak indicating changes in ploïdy level could be found.

\section{Discussion}

The regeneration process developed for the sahelian date palm cultivars allowed the production of somatic embryoderived plantlets through indirect embryogenesis involving two callogenesis stages and embryogenic suspensions culture. Each step was optimised by using various PGR concentrations.

The aptitude for primary callogenesis appeared to be strongly dependent on the explant nature, the genotype, and the growth regulators used. The foliar segments from young date palm seedlings was found to be the optimal explant for callus induction compared to root tissues. For the four cultivars under study, primary callogenesis led to the formation of globular compact calluses similar to those described in Elaeis guineensis [15] and Phoenix canariensis [6].

The callogenic capacity was found to be more than seven times higher for the cultivars Ahmar and Amsekhsi than for the cultivars Tijib and Amaside. At the date palm was found that the genotype is one of the most important factors in the induction of primary callus [11]. Similar observations were made on coconut [20]. The reason(s) of the recalcitrance to callogenesis of some genotypes still remain unknown. The hypothesis of a genetic inability to callus formation was proposed, respectively, in Medicago sativa and Zea mays $[21,22]$. The identification of quantitative trait loci (QTLs) associated with callogenesis and embryogenesis has been undertaken using molecular markers obtained from Arabidopsis thaliana tissue culture cDNA libraries [23]. Genetic mapping of such markers would allow the selection of genotypes with high ability to tissue culture.

The phase of cell multiplication, related to the sensitivity to the 2,4-D of foliar tissues of date palm, occurs as of the 2nd week of culture [10] and leads to the formation of the primary calluses after the 4 th week of culture. The callogenesis stage requires the use of elevated exogenous auxin levels in many species [12]. The effect of the 2,4D during cellular dedifferentiation was strongly correlated with an increase in endogenous AIA in carrot tissues [24]. Indeed, results obtained in Medicago sativa showed that concentrations in endogenous AIA increased considerably during the first 3 days of culture in the presence of optimal concentrations of 2,4-D [25]. The accumulation of endogenous AIA in tissues under 2,4-D treatment would be at the origin of the totipotency of somatic cells in Zea mays and consequently of their capacity to be directed towards embryogenesis [26].

Recent advances in auxin biology have clarified the mode of action, signalling, and gene expression of this plant hormone $[27,28]$. Auxin induces the expression of several genes including $A u x / I A A$, GH3 (IAA-aminoacid conjugating enzyme), and glutathione $S$-transferase [12, 29]. GH3 protein homologs were strongly induced in response to 2,4$\mathrm{D}$ [30], suggesting that this auxinomimetic could use the signalling pathway, at least partly, of auxin response.

In this study, the high callogenesis rates obtained for Ahmar and Amsekhsi cultivars in the presence of the combinations of 2,4-D with BA or adenine sulphate, which 
TABLE 2: Influence of NAA on rooting after 4 weeks.

\begin{tabular}{lcc}
\hline NAA $(\mathrm{mg} / \mathrm{L})$ & $\begin{array}{c}\text { Root number } \\
\text { per plant }\end{array}$ & $\begin{array}{c}\text { Root lengh } \\
(\mathrm{cm})\end{array}$ \\
\hline 0 & $13^{\mathrm{a}}$ & $1.4^{\mathrm{b}}$ \\
1 & $1^{\mathrm{b}}$ & $4.9^{\mathrm{a}}$ \\
\hline
\end{tabular}

Average values were calculated from 5 repetitions per condition of medium; letters indicate significative differences according to Newman and Keuls test at the level of $5 \%$.

TABle 3: Quantification of nuclear DNA from cells of leaf tissue of seedlings and clones produced from cell suspensions in cultivars Ahmar and Amsekhsi.

\begin{tabular}{lccc}
\hline Genotypes & qADN $(\mathrm{pg})$ & $\begin{array}{c}\text { Standard } \\
\text { deviation } \\
(\mathrm{pg})\end{array}$ & $\begin{array}{c}\text { Number of } \\
\text { repetitions }\end{array}$ \\
\hline Ahmar clones & 1,72 & 0,01 & 15 \\
Ahmar seedlings & 1,74 & 0,02 & 7 \\
Amsekhsi clones & 1,73 & 0,01 & 18 \\
Amsekhsi seedlings & 1,73 & 0,02 & 10 \\
\hline
\end{tabular}

may act as a precursor of natural cytokinin [31] stresses the importance of the auxin/cytokinin balance during the early steps of embryogenesis in date palm. The addition of BA in culture media already containing 2,4-D also improved callogenesis rates in Acacia raddiana [32]. The dedifferenciation of protoplasts obtained from foliar cells of alfalfa could also optimize varying the auxin/cytokinin balance [25]. Both auxins and cytokinins can trigger somatic cells to differentiate into embryogenic competent cells [12]. During the somatic-to-embryogenic transition in Arabidopsis thaliana, transcription factors such as $B A B Y B O O M$ $(B B M)$ and LEAFY COTYLEDON 1 (LEC1) were activated $[23,33]$. Ectopic expression of $B B M$ and $L E C 1$ was sufficient to induce somatic embryo development from vegetative cells $[23,33]$. It would be very interesting to study the effect of PGRs on the expression of such a gene in palm leaf tissues in relation to callogenesis progression and rates.

Whatever the hormonal balance experimented in this study, both cultivars Tijib and Amaside were found to be weakly callogenic. The recalcitrance of such genotypes could be overcome by the use of other auxins and cytokinins that were reported to be efficient for the induction of callogenesis in several palm species. In the betelnut palm (Areca catechu), callogenesis was induced on medium containing Dicamba, an auxinomimetic PGR [34]. In Phoenix canariensis, callogenesis was induced from shoot tips with 2,4-D and 2iP (2isopentenyl adenin) or with Picloram and kinetin [6]. The combination of 2,4-D and 2iP was also found efficient in inducing callus development in date palm $[3,35]$.

The granular secondary calli used for the initiation of suspensions were obtained by chopping primary calli. Two to four subcultures were necessary to establish suspensions culture in the presence of 2,4-D. These suspensions consisted of embryogenic clumps [10] whose multiplication rate reached threefold on 2,4-D (2 $\left.\mathrm{mg} \mathrm{L}^{-1}\right)$ containing medium. To ensure the development of somatic embryos, it was

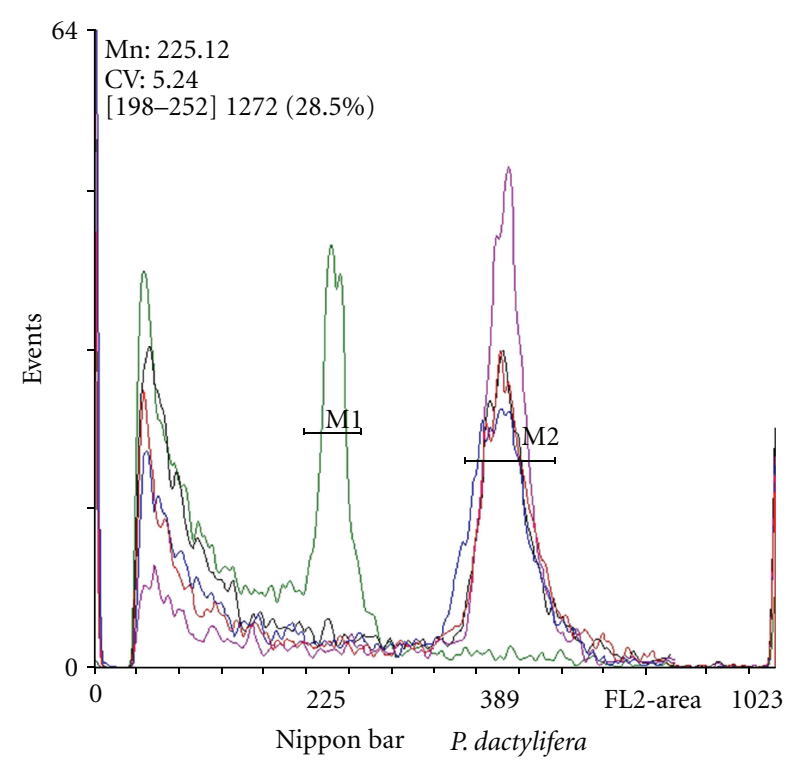

FIGURE 4: Flow cytometry analysis of nuclear DNA from leaves of rice (Nippon bar) seedlings (green), date palm cv. Ahmar seedlings (violet), and date palm cv. Ahmar somatic embryo-derived plantlets (red, black, and blue).

necessary to modify the hormonal balance in favour of the cytokinins. The transitory application of $\mathrm{BA}\left(0,5 \mathrm{mg} \mathrm{L}^{-1}\right)$ improved embryo development after only 5 weeks. The omission of 2,4-D from the culture medium followed by the addition of BA enhanced the differentiation of proembryos toward bipolar embryos in oil palm [16] and coconut [36].

Under our experimental conditions, the development and subsequent germination of embryos were carried out on gelified PGR-free media. The germination rates of stage III embryos reached $82 \%$. The application of NAA $\left(1 \mathrm{mg} \cdot \mathrm{L}^{-1}\right)$ favoured rooting as already shown for $P$. canariensis [6] and $P$. dactylifera [10]. NAA induced the formation of a primary orthogravitropic root comparable to that developed during in vitro germination of oil palm seeds [37]. This root system may be more efficient during the critical acclimatization phase of the plantlets.

The somatic embryogenesis process described here allowed the production of approximately 10,000 individualized embryos from $15 \mathrm{~g}$ of suspension culture. It constitutes a first step towards the development of large-scale regeneration protocols for sahelian date palm cultivars. Our results illustrate the importance of PGR concentrations and of the balance between auxins and cytokinins in the optimisation of regeneration protocols. For each genotype the identification of optimal PGR concentrations is essential. However, PGR application needs to be optimized while keeping in mind the risk of induction of somaclonal variations. Indeed, somaclonal variations such as variegations and fruit set abnormalities in tissue-culture-produced date palm have already been reported [38]. Cytofluorimetric analyses revealed that the regeneration process under study did not induce any detectable change in ploïdy level and DNA content of regenerated plantlets. It must be noticed that more discrete changes in DNA such as aneuploidy cannot be 
detected using cytofluorimetry. Furthermore, an epigenetic origin for somaclonal variants has been proposed in oil palm [39] and date palm [38]. In oil palm, a correlation between somaclonal variation and the methylation status of genomic DNA has been established [39]. In this case, off-types could not be identified by techniques relaying on genomic DNA sequence analyses [40]. To limit the risks of producing somaclonal variants, PGR concentrations and applications need to be lowered and protocols need to be evaluated regarding clonal fidelity in the field.

\section{Acknowledgments}

M. Saleck and the University of Nouakchott (Mauritania) facilitated the access to germplasm in the Atar region. The authers thank the International Foundation for Science (IFS, Grant D/3234-1) and the Support and Training Department (DSF) of the French Institut de Recherche pour le Développement (IRD) for granting this work.

\section{References}

[1] O. Reuveni, "Embryogenesis and plantlets growth of date palm (Phoenix dactylifera L.) derived from callus tissue," Plant Physiology, vol. 63, p. 138, 1979.

[2] J. F. Reynolds and T. Murashige, "Asexual embryogenesis in callus cultures of palms," In Vitro, vol. 15, no. 5, pp. 383-387, 1979.

[3] B. Tisserat and D. A. Demason, "A histological study of development of adventive embryos in organ cultures of Phoenix dactylifera L.," Annals of Botany, vol. 46, no. 4, pp. 465-472, 1980.

[4] B. Tisserat, "Propagation of date palm (Phoenix dactylifera L.) in vitro," Journal of Experimental Botany, vol. 30, no. 6, pp. 1275-1283, 1979.

[5] F. Daguin and R. Letouze, "Regeneration of date palm (Phoenix dactylifera) by somatic embryogenesis: improved effectiveness by dipping un a stirred liquid medium," Fruits, vol. 43, pp. 191-194, 1988.

[6] L. T. L. Huong, M. Baiocco, B. P. Huy, B. Mezzetti, R. Santilocchi, and P. Rosati, "Somatic embryogenesis in Canary Island date palm," Plant Cell, Tissue and Organ Culture, vol. 56, no. 1, pp. 1-7, 1999.

[7] S. Bhaskaran and R. H. Smith, "Somatic embryogenesis from shoot tip and immature inflorescence of Phoenix dactylifera cv. Barhee," Plant Cell Reports, vol. 12, no. 1, pp. 22-25, 1992.

[8] L. Fki, R. Masmoudi, N. Drira, and A. Rival, "An optimised protocol for plant regeneration from embryogenic suspension cultures of date palm, Phoenix dactylifera L., cv. Deglet Nour," Plant Cell Reports, vol. 21, no. 6, pp. 517-524, 2003.

[9] J. Zouine, M. El Bellaj, A. Meddich, J.-L. Verdeil, and I. El Hadrami, "Proliferation and germination of somatic embryos from embryogenic suspension cultures in Phoenix dactylifera," Plant Cell, Tissue and Organ Culture, vol. 82, no. 1, pp. 83-92, 2005.

[10] D. Sané, F. Aberlenc-Bertossi, Y. K. Gassama-Dia et al., "Histocytological analysis of callogenesis and somatic embryogenesis from cell suspensions of date palm (Phoenix dactylifera L.)," Annals of Botany, vol. 98, no. 2, pp. 301-308, 2006.

[11] M. F. Gabr and B. Tisserat, "Propagating palms in vitro with special emphasis on the date palm (Phoenix dactylifera L.)," Scientia Horticulturae, vol. 25, no. 3, pp. 255-262, 1985.
[12] A. Féher, T. P. Pasternak, and D. Dudits, "Transition of somatic plant cells to an embryogenic state. Review of plant biotechnology and applied genetics," Plant Cell, Tissue and Organ Culture, vol. 74, no. 3, pp. 201-228, 2003.

[13] T. Murashige and F. Skoog, "A revised medium for rapid growth and biassays with tobacco tissue cultures," Physiologia Plantarum, vol. 15, no. 3, pp. 473-497, 1962.

[14] G. Morel and R. M. Wetmore, "Fern callus tissue culture," American Journal of Botany, vol. 38, no. 2, pp. 141-143, 1951.

[15] J. B. Teixeira, M. R. Sondahl, T. Nakamura, and E. G. Kirby, "Establishment of oil palm cell suspensions and plant regeneration," Plant Cell, Tissue and Organ Culture, vol. 40, no. 2, pp. 105-111, 1995.

[16] F. Aberlenc-Bertossi, M. Noirot, and Y. Duval, "BA enhances the germination of oil palm somatic embryos derived from embryogenic suspension cultures," Plant Cell, Tissue and Organ Culture, vol. 56, no. 1, pp. 53-57, 1999.

[17] M. D. Bennett and J. B. Smith, "Nuclear DNA amounts in angiosperms," Philosophical Transactions of the Royal Society of London B, vol. 334, pp. 309-345, 1991.

[18] J. Dolezel and P. Binarová, "The effects of colchicine on ploidy level, morphology and embryogenic capacity of alfalfa suspension cultures," Plant Science, vol. 64, no. 2, pp. 213-219, 1989.

[19] D. W. Galbraith, K. R. Harkins, J. M. Maddox, N. M. Ayres, D. P. Sharma, and E. Firoozabady, "Rapid flow cytometry analysis of the cell cycle in intact plant tissues," Science, vol. 220, no. 4601, pp. 1049-1051, 1983.

[20] J.-L. Verdeil, C. Huet, F. Grosdemange, and J. Buffard-Morel, "Plant regeneration from cultured immature inflorescences of coconut (Cocos nucifera L.): evidence for somatic embryogenesis," Plant Cell Reports, vol. 13, no. 3-4, pp. 218-221, 1994.

[21] O. C. W. Brown, "Germplasm determination of in vitro somatic embryogenesis in alfalfa," Hort Science, vol. 23, no. 3, pp. 526-531, 1988.

[22] D. T. Tomes, "Cell culture, somatic embryogenesis and plant regeneration in maize, rice, sorghum and millets," in Cereal Tissue and Cell Culture, S. M. J. Bright and M. G. K. Jones, Eds., pp. 175-203, Martinus Nijhoff/Junk, Amsterdam, The Netherlands, 1985.

[23] T. Lotan, M. Ohto, K. M. Yee et al., "Arabidopsis LEAFY COTYLEDON1 is sufficient to induce embryo development in vegetative cells," Cell, vol. 93, no. 7, pp. 1195-1205, 1998.

[24] L. Michalczuk, D. M. Ribnicky, T. J. Cooke, and J. D. Cohen, "Regulation of indole-3-acetic acid biosynthetic pathways in carrot cell cultures," Plant Physiology, vol. 100, no. 3, pp. 13461353, 1992.

[25] T. Pasternak, P. Miskolczi, F. Ayaydin, T. Mészaros, D. Dudits, and A. Fehér, "Exogenous auxin and cytokinin dependent activation of CDKs and cell division in leaf protoplast-derived cells of alfalfa," Plant Growth Regulation, vol. 32, no. 2-3, pp. 129-141, 2000.

[26] V. M. Jemenez and F. Bangerth, "Hormonal status of maize initial explants and of the embryogenic and non-embryogenic callus cultures derived from them as related to morphogenesis in vitro," Plant Science, vol. 160, no. 2, pp. 247-257, 2001.

[27] N. Dharmasiri and M. Estelle, "Auxin signaling and regulated protein degradation," Trends in Plant Science, vol. 9, no. 6, pp. 302-308, 2004.

[28] S. Vanneste and J. Friml, "Auxin: a trigger for change in plant development," Cell, vol. 136, no. 6, pp. 1005-1016, 2009.

[29] P. E. Staswick, B. Serban, M. Rowe et al., "Characterization of an arabidopsis enzyme family that conjugates amino acids to indole-3-acetic acid," Plant Cell, vol. 17, no. 2, pp. 616-627, 2005. 
[30] R. M. Wright, G. Hagen, and T. Guilfoyle, "An auxin-induced polypeptide in dicotyledonous plants," Plant Molecular Biology, vol. 9, no. 6, pp. 625-634, 1987.

[31] E. F. George and P. D. Sherrington, "Plant Propagation by Tissue Culture," in Plant Propagation by Tissue Culture, Handbook of Directory and Commercial Laboratories, E. F. George and P. D. Sherrington, Eds., p. 305, Exegetics Eversley, London, UK, 1984.

[32] D. Sané, A. Borgel, J.-L. Verdeil, and Y. K. Gassama-Dia, "Plantlet regeneration via somatic embryogenesis in immature zygotic embryo callus from a tree species adapted to arid lands: acacia tortilis subsp.raddiana (Savi.) Brenan," Acta Botanica Gallica, vol. 147, pp. 257-266, 2000.

[33] K. Boutilier, R. Offringa, V. K. Sharma et al., "Ectopic expression of BABY BOOM triggers a conversion from vegetative to embryonic growth," Plant Cell, vol. 14, no. 8, pp. 1737-1749, 2002.

[34] H. C. Wang, J. T. Chen, and W. C. Chang, "Somatic embryogenesis and plant regeneration from leaf, root and stem-derived callus cultures of Areca catechu," Biologia Plantarum, vol. 50, no. 2, pp. 279-282, 2006.

[35] J. Veramendi and L. Navarro, "Influence of physical conditions of nutrient medium and sucrose on somatic embryogenesis of date palm," Plant Cell, Tissue and Organ Culture, vol. 45, no. 2, pp. 159-164, 1996.

[36] J.-L. Verdeil, V. Hocher, C. Huet et al., "Ultrastructural changes in coconut calli associated with the acquisition of embryogenic competence," Annals of Botany, vol. 88, no. 1, pp. 9-18, 2001.

[37] C. Jourdan, N. Michaux-Ferriere, and G. Perbal, "Root system architecture and gravitropism in the oil palm," Annals of Botany, vol. 85, no. 6, pp. 861-868, 2000.

[38] Y. Cohen, R. Korchinsky, and E. Tripler, "Flower abnormalities cause abnormal fruit setting in tissue culture-propagated date palm (Phoenix dactylifera L.)," Journal of Horticultural Science and Biotechnology, vol. 79, no. 6, pp. 1007-1013, 2004.

[39] E. Jaligot, A. Rival, T. Beulé, S. Dussert, and J. L. Verdeil, "Somaclonal variation in oil palm (Elaeis guineensis Jacq.): the DNA methylation hypothesis," Plant Cell Reports, vol. 19, no. 7, pp. 684-690, 2000.

[40] A. Rival, L. Bertrand, T. Beulé, M. C. Combes, P. Trouslot, and P. Lashermes, "Suitability of RAPD analysis for the detection of somaclonal variants in oil palm (Elaeis guineensis Jacq.)," Plant Breeding, vol. 117, no. 1, pp. 73-76, 1998. 


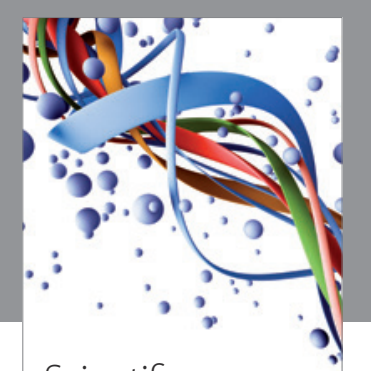

Scientifica
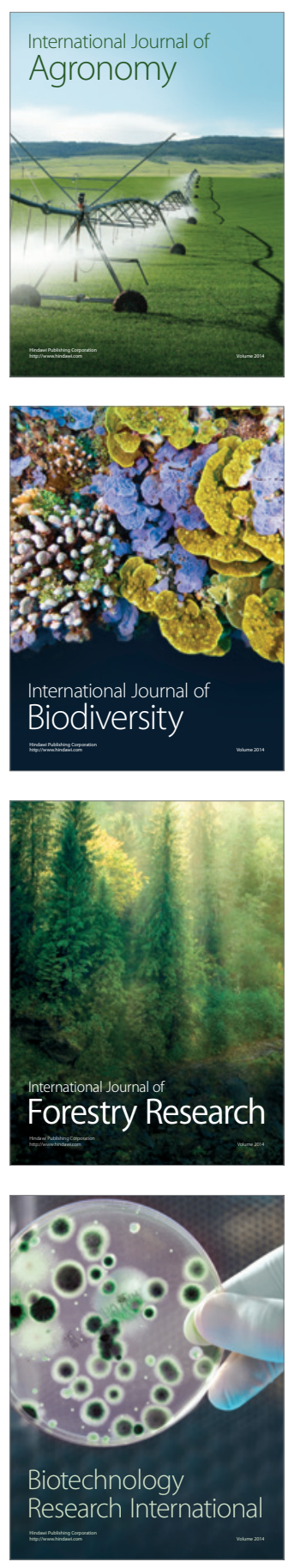
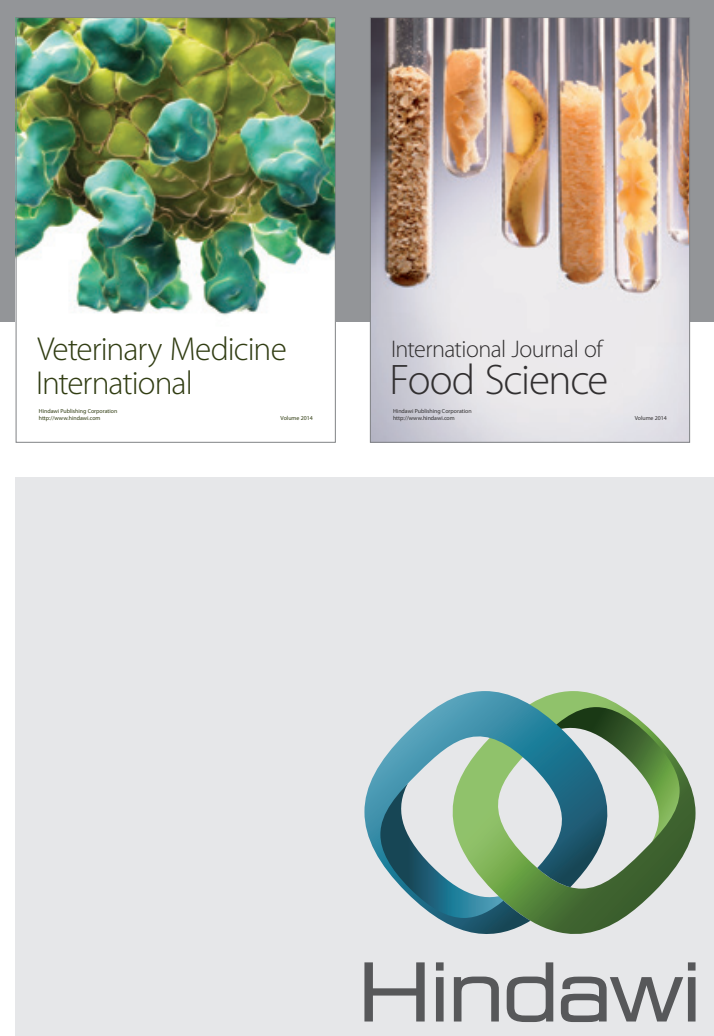

Submit your manuscripts at

http://www.hindawi.com
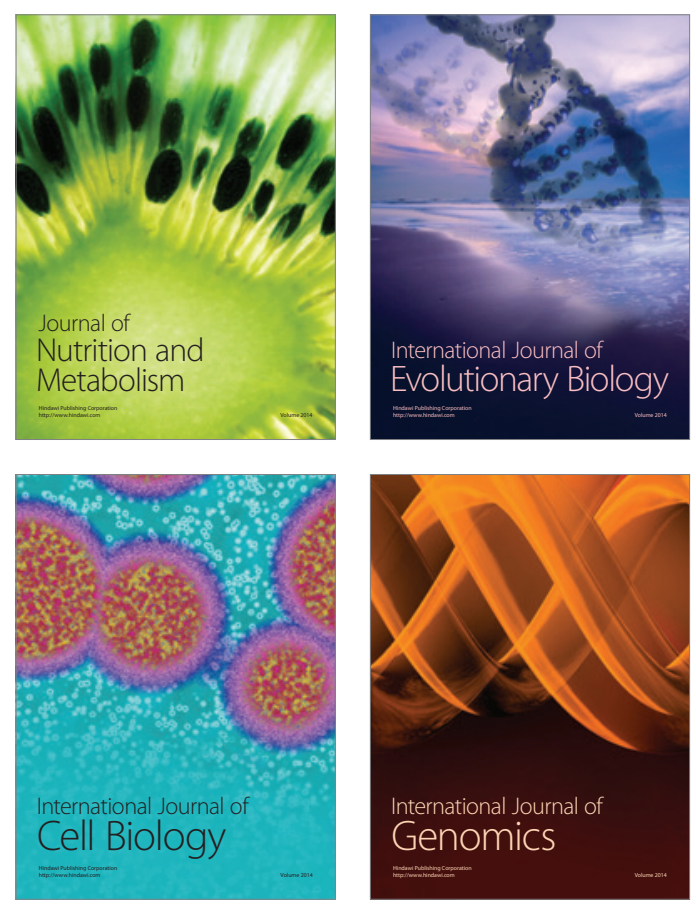
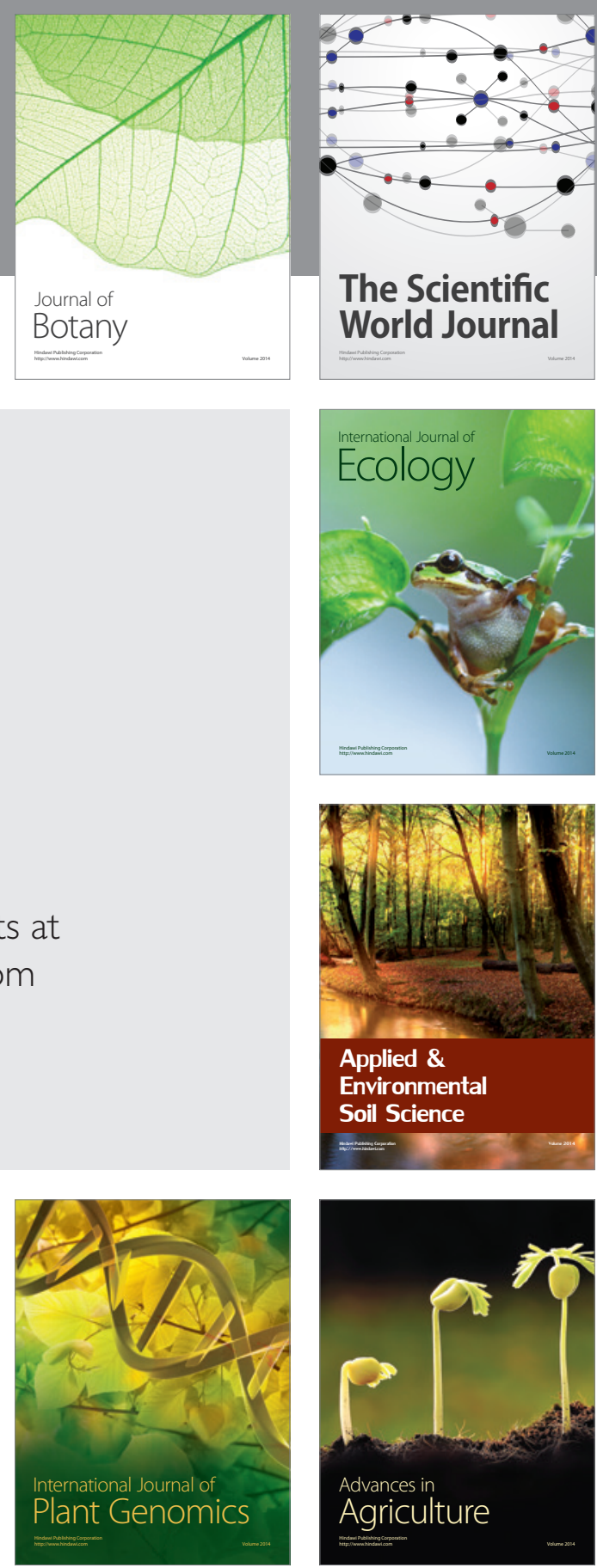

The Scientific World Journal
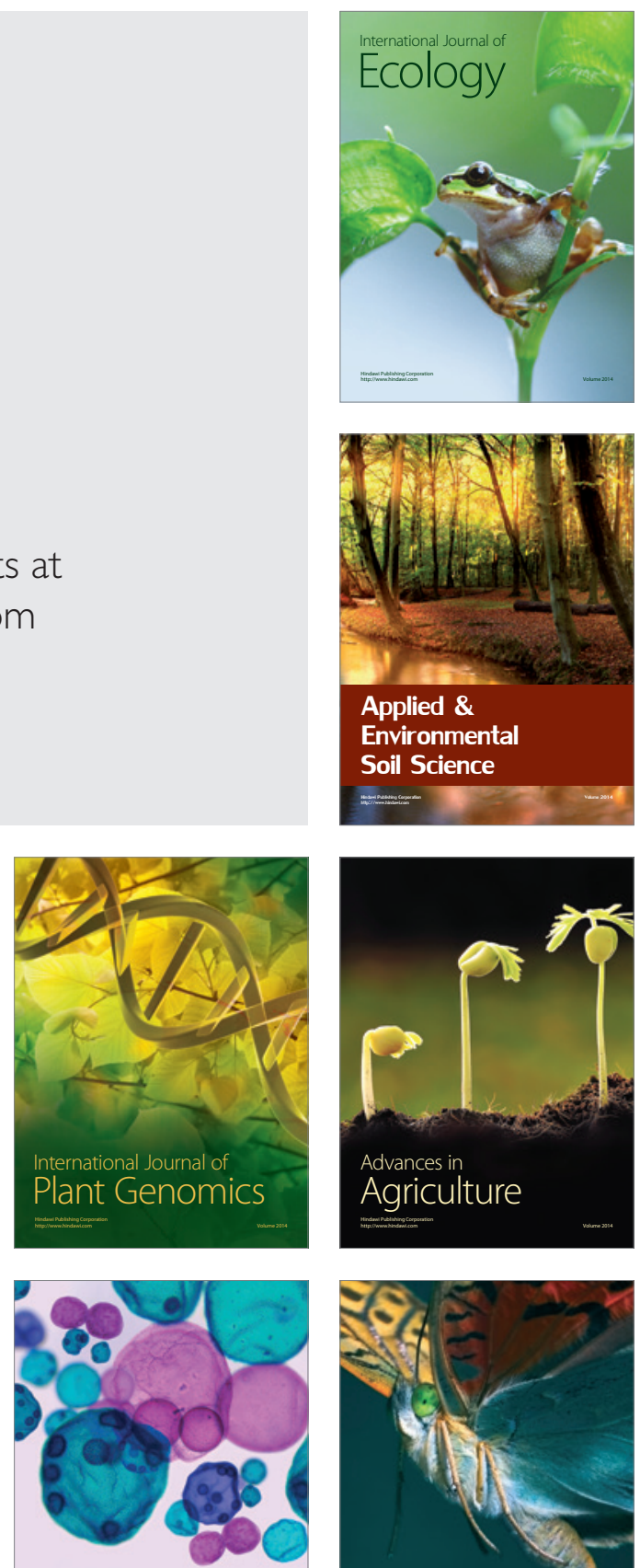

International Journal of Microbiology

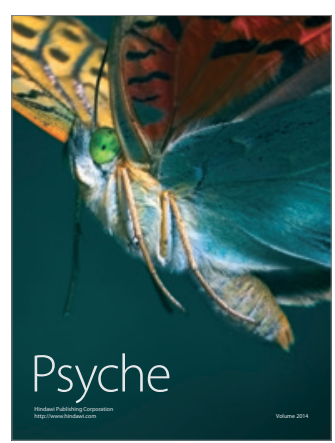

